\section{THE “ZENITH” BALLOON ASCENT}

$\mathrm{O}^{\mathrm{N}}$

Monday, M. Gaston Tissandier read a paper before the Paris Academy of Sciences on the recent fatal balloon ascent, in which he expressed his deliberate intention of renewing the attempt. The real cause of the catastrophe was the throwing out of ballast at an immense height; Tissandier attributes it to the "vertigo of high regions." The pain felt is so small that one torgets the danger in wishing to reach a higher level; so that he who is not able to restrain himself is not fitted to be an aëronaut in high regions.

The carbonic acid tubes having been broken in the fall, no analysis could be made, and consequently it is necessary to make another ascent in order to complete the experiment.

The figures given by M. Tissandier in his paper are substantially the same as those given in last week's NATURE (p. 495). The height reached was 8,600 meters, as proved by maximum-barometers, which had been sealed up, and were opened in the laboratory of the Sorbonne.

I believe the rapidity of ascent, but mainly the gas which escaped from the balloon, were instrumental in the deaths of Sivel and Crocé-Spinelli.

The matter deserves to be carefully investigated, and I shall try to elucidate it by an ascent which I propose to make next Sunday from La Villette, with Duruof and the Times correspondent. Our intention is not to make a race for a high altitude, and we will do our best to resist the vertigo of high regions so vividly described by Tissandier in his paper.

W. DE FONVIELLE

\section{I.ECTURES AT THE ZOOLOGICAL GARDENS}

$\mathrm{O}$ Thursday, April 15 , the first of the ten lectures announced for the present season was given by Mr. Sclater, F.R.S. "On Monkeys and their Geographical Distribution."

After referring to the considerable series of monkeys in the Society's collection, from which a specimen of the Chimpanzee (Troglodytes niger), of an albino Macaque Monkey (Macacus (ynomolgus), and others were exhibited, Mr. Sclater drew attention to the six zoological provinces into which the surface of the earth was generally acknowledged to be divided. These he had named and defined as follows:-

r. Palcarctic Region. - Europe, Africa north of the Atlas, and North Asia.

2. Ethiopian Region.-Africa south of the Atlas, and Madagascar.

3. Indian Region.-South Asia, Philippines, and Islands of Indian Archipelago to Wallace's Line.

4. Nearctic Region. - North America down to Isthmus of Tehuantepec.

5. Neotropical Region.-Central America, south of the Isthmus of Tehuantepec, and South America.

6. Australian Region.-Australia, New Guinea, and AustroMalay Archipelago. No monkeys being found in the Australian or Nearctic regions, and none in the Palæarctic, except the Macaque of North Africa and Gibraltar.

Commencing with the Anthropoid Apes, the Gorilla (Troglo dytes gorilla) was shown to inhabit the tropical regions of West Africa only, not extending south beyond the River Gaboon. The same region is the home of the Chimpanzee, which, however, snreads to the east for a considerable distance, having been captured in Abyssinia. It is also found as far south as the north bank of the River Congo. Of the two other genera of Anthropoid Apes, the Orang Utan and the Gibbon, the former is confined to Borneo and Sumatra, the latter to the Malay Peninsula, Assam, and the islands of the Indo-Malay Archipelayo.

Of the Catarrhine or Old World Monkeys, there is a peculiar lnng-tailed genus, Semnopithecus, found in India and the Malay region. This is represented in Africa by the similarly peculiar genus Colobus, which wants the thumb; it is found mostly in West Africa, extending east as far as Abyssinia. Of this group the Indian Eatellus Monkey is best known. The genus Macacus is almost confined to the Indian region; a species ( $M$. speciosus) is, however, found in Japan; and the Barbary Ape (M. innus) from Ape's Hill has crossed to Gibraltar. The genera Cercopithecus and Cynocephalus are confined to the Ethiopian region.

The Platyrrhine Monkeys, with an extra premolar on each side of each jaw, are inhabitants of the tropical portions of the Neotropical region only. Amongst them are included the genera Cebus, Ateles, Mycetes, Brachyurus, and others, some with, and others without, prehensile tails, many of which have, at one time or other, lived in the Society's Gardens. The Marmosets have one less molar in each half of each jaw, which makes the number of their teeth the same as in man, althuugh this is the consequence of there being four more premolars and four fewer true molars.

The Lemuridæ, whether they ought to be included with the monkeys, or whether they form an independent group, may be considered with the quadrumana, as has been usually the case. They are distributed throughout the Ethiopian and Indian regions, nearly all the species, including Chiromys, being confined to Madagascar, which must be considered their true headquarters.

The following is an abstract of Mr. J. W. Clark's lecture on Sea Lions, delivered on April 22nd.- The Pinnipedia, com. prising the Sea Lion, Sea Bear, Seal, and Walrus, are true mammalian animals, entirely differing from fish both in structure and habit. The Order naturally talls into two subdivisions, narnely, the Eared and the Earless Seals; or, the Otariadæ, otherwise called Sea Lions, and the Trichechidæ (Walrus), together with the Cystophoridæ (Bladder-nosed Seals) and Phocidæ. (True Seals). The former of these groups, the Otariadæ, differ from the Seals, the Phocidx, in other respects than the possession of ears. They can use their limbs freely to raise the body from the ground and to walk on the land. They can even run swiftly for a short distance. The Seals, on the contrary, always retain their hind feet stretched out backwards, the legs being so enclosed within the integument of the body that they bave little or no independent motion. They consequently are only able to progress on land by a series of ungraceful bumps, wriggling on the stomach. The body of the Sea Lion is peculiarly flexitle, whilst that of the Seal has but little motion on its axis, the animal progressing in the water in much the same manner as the Porpoise. The Sea Lion's head is also more elongated and narrow in proportion to its width than that of any Seal. Its ears are small, conical organs, projecting backwards, and so rolled up, scrollwise, that their concavity is rarely shown. But by far the most modifed portions of the body of the Sea Lion are the hands and feet. In the Seal the arm is wholy imbedded in the integument, the hand alone projecting. In the Sea Lion, on the contrary, nearly the whole of the upper half of the limb is free, and the thumb is much lengthened, this digit in the Seals being of the $s$ me len $h$ as the others. In the hinder extremity the lo er vart of the leg and the foot are free, the rest of the limb being bound up with the body.

With regard to the skin of the Sex Lion; on a superf ial view the body appears to be covered with coarse stiff hair, which varies in length on different parts. Old males are satd to $d$ :velon a mane, whence the name given them by early voyagers, but it is not certain that this ornament is present in all the species, Beneath this hair there is a crop of under wool, distributed in delicate, short, fine hairs set at the base of the other larger ones. It appears to exist all over the body.

This part of the subject is rather involved. It is stated that of these Otarias, or Sea Lions, some species have under-furwhilst others have not, and attempts have been made to divide them into families accordingly. It is, however, highly probable that all Otarias have under-fur at some period of their lives. It is this under-fur of the Sea Lions which makes that sealskin in which all ladies delight.

The habits of the Sea Lion are among the most curious in the whole of the animal kingdom. Its food consists mostiy of fish, mollusca, crabs, and penguins. Th molar teeth being small, it cannot masticate its food, and when it has caught a fish, too large to be swallowed outright, it has been seen to give its head a sudden twist, so as to break off a portion of the fish, which it swallows rapidly. It then dives into the water, picks up the other portion, and repeats the tearing process until the last fragment is devoured.

Their favourite places of resort are solitary islands, either far out at sea, or at any ra:e clear of an inbabited coast. Many return year after year to the same rock. The natives at the 